\title{
Acoustic characterisation of bycatch mitigation pingers on shark control nets in Queensland, Australia
}

\author{
Christine Erbe $^{1,2, *}$, Craig McPherson ${ }^{1}$ \\ ${ }^{1}$ JASCO Applied Sciences Australia, Brisbane Technology Park, Eight Mile Plains, Queensland 4113, Australia \\ ${ }^{2}$ Present address: Centre for Marine Science \& Technology, Curtin University, Kent Street, Bentley, \\ Western Australia 6102, Australia
}

\begin{abstract}
The Queensland Shark Control Program (QSCP) uses pingers to prevent marine mammal entanglement in shark control nets along public beaches, in Queensland, Australia. Acoustic emissions of Fumunda F3 (designed for humpback whales) and F10 pingers (designed for dolphins) were measured and characterised. The acoustic signals consisted of tones ( 3 and $10 \mathrm{kHz}$, respectively) and harmonic overtones emitted for about $400 \mathrm{~ms}$ every 5 to $6 \mathrm{~s}$. Directivity was more pronounced for the overtones. Broadband source levels were up to $135 \mathrm{~dB}$ re $1 \mu \mathrm{Pa}$ at $1 \mathrm{~m}$ for all pingers at all angles. Ambient noise was recorded in the vicinity of shark nets for 3 wk each quarter of 1 yr. Fish choruses, migrating humpback whales, dolphins, snapping shrimp, boats, sandpumps, wind and wave noise were identified. Beyond $1.5 \mathrm{~km}$, pingers no longer contributed significantly to the ambient noise budget. Sound propagation was modelled to relate received pinger tones to measured ambient levels and to estimate the potential detection of pingers by local marine mammals (humpback whales, dugongs, dolphins). Mean transmitted levels were predicted to be audible over up to a few $100 \mathrm{~m}$ in range (depending on species). With currently 3 to 4 pingers per shark net of $200 \mathrm{~m}$ length, existing pinger type and arrangement were modelled to be adequate, even for marine mammals swimming straight at a net at top speed. Additional behavioural studies or long-term monitoring are needed to determine pinger efficacy.
\end{abstract}

KEY WORDS: Pinger · Bycatch $\cdot$ ADD $\cdot$ Acoustic deterrence $\cdot$ Noise budget

\section{INTRODUCTION}

Pingers, or acoustic alarms, were developed to reduce bycatch of marine mammals in fishing gear (Reeves et al. 1996, Werner et al. 2006). Pingers are most commonly used in gill net fisheries across the United States and by member states of the European Union (Kastelein et al. 2007, Gotz \& Hastie 2009). In Australia, pingers for bycatch mitigation and depredation mitigation are under consideration for active utilisation by the commercial fishing industry in most states. Several acoustic devices are readily available throughout Australia. Applications include purse seine, trawl, gillnet and various baited line fisheries. Acoustic alarms have been used by the Queensland Shark Control Program (QSCP) since 1992; the history of the acoustic alarm strategy employed in coastal Queensland gill net fisheries, and by the QSCP, is outlined in McPherson et al. (2001).

A variety of acoustic alarms exist, emitting pure tones, amplitude-modulated tones, frequency sweeps and broadband-pulsed sounds, as well as a series of multiple sounds. Most commercial pingers range from 3 to $130 \mathrm{kHz}$. High-frequency outputs of $>70 \mathrm{kHz}$ are aimed at animals with good high-frequency hearing such as harbour porpoises Phocoena phocoena 
(Kastelein et al. 2007, 2008), while lower frequency outputs are aimed at marine animals with lowfrequency hearing sensitivity such as humpback whales Megaptera novaeangliae. Using a pinger designed for one species often does not evoke the same behavioural effect on others (Kastelein et al. 2006, Berrow et al. 2008, Brotons et al. 2008). Establishing the likely sensitive hearing ranges of the relevant marine mammal species will assist in pinger device selection and will increase the probability of success.

The main goal of bycatch-mitigation pingers on gill nets is to 'highlight' the nets, notifying marine mammals of their presence and location and hence reducing entanglements (Kastelein et al. 2007). For example, Aquatech pingers (frequency modulated [FM]: between 20 and $160 \mathrm{kHz}$; source level [SL]: $165 \mathrm{~dB}$ re $1 \mu \mathrm{Pa}$ at $1 \mathrm{~m}$ ) reduced negative interactions of bottlenose dolphins Tursiops truncatus with nets in the Shannon Estuary in Ireland through behavioural changes without unduly deterring the dolphins from use of their habitat (Leeney et al. 2007). Dukane NetMark 1000 pingers (10 to $12 \mathrm{kHz}$ tones + overtones up to $100 \mathrm{kHz}, 300 \mathrm{~ms}$ duration every $4 \mathrm{~s}$, SL $132 \mathrm{~dB}$ re $1 \mu \mathrm{Pa}$ at $1 \mathrm{~m}$ ) significantly reduced bycatch of common dolphin Delphinus delphis, beaked whales and other oceanic delphinids in gillnets in California and Oregon, USA (Barlow \& Cameron 2003, Carretta et al. 2008). Low-intensity gillnet bycatch pingers were attached to trawl nets but failed to reduce bycatch and depredation-associated mortality of oceanic delphinids (Reijnders 2006, Stephenson \& Wells 2008). The acoustic noise field around operating fish trawls can be expected to mask aspects of the pinger signals. Higher intensity Dolphin Dissuasive Device (DDD) pingers by STM Products (emitting a variety of broadband and FM tonal signals, SL $175 \mathrm{~dB}$ re 1 $\mu \mathrm{Pa}$ at $1 \mathrm{~m}$ ) were more effective at reducing bycatch in trawl nets (Northridge \& Kingston 2009). Amir (2009) found that Fumunda F10 pingers reduced Indo-Pacific bottlenose T. aduncus and humpback dolphin Sousa chinensis bycatch in both drift and bottom-set gillnets in Menai Bay, Zanzibar. Australian bottlenose T. aduncus and Indo-Pacific humpback dolphins exhibited aggressive responses to 10 $\mathrm{kHz}$ devices deployed singly and on QSCP nets (McPherson et al. 2004).

Hodgson (2004) and Hodgson et al. (2007) tested short-term behavioural responses of dugongs $\mathrm{Du}$ gong dugon in Moreton Bay, Queensland, to BASA pingers (4 and $10 \mathrm{kHz}$, SL $133 \mathrm{~dB}$ re $1 \mu \mathrm{Pa}$ at $1 \mathrm{~m}$ ). Two pingers were deployed simultaneously 50 to $55 \mathrm{~m}$ apart, similar to pinger spacing on a net; how- ever, there was no actual net in the experiment. No significant responses were observed during daylight operations in clear water: dugongs passed between pingers whether they were active or inactive, fed throughout the experiments, did not change their orientation to avoid or investigate the pingers and did not change their likelihood of vocalising. However, the pingers tested were not intended to actively divert animals. Also, during the daylight in clear water, dugongs might have seen that there was no physical barrier such as a net between the pingers. The pingers were lowered into and raised above the water for the experimental and control conditions; however, the pingers in the air immediately above the water would have transmitted into the water (at least within a $26^{\circ}$ cone), and for dugongs swimming in between and around pingers, the experimental (pinger on) and control (pinger off) conditions might not have been very different.

On the other hand, McPherson et al. (2004) reported dugongs approaching and then moving around nets fitted with pingers emitting $3 \mathrm{kHz}$ at 135 to $138 \mathrm{~dB}$ re $1 \mu \mathrm{Pa}$ at $1 \mathrm{~m}$ during the hours of darkness and in turbid northern Queensland waters. Ichikawa et al. (2009) demonstrated for wild dugongs in Thailand that playbacks of sounds of actual or synthetic dugong calls attracted dugongs to within 10 and $19 \mathrm{~m}$, respectively, from within a $250 \mathrm{~m}$ radius. Playback of $3.5 \mathrm{kHz}$ tones of $141 \mathrm{~dB}$ re $1 \mu \mathrm{Pa}$ at $1 \mathrm{~m} \mathrm{SL}$ resulted in a stand-off distance of $100 \mathrm{~m}$.

It is often assumed that 'habituation' would lead to increased bycatch. However, this has never been demonstrated in longer term studies (Carretta et al. 2008, Palka et al. 2008). The opposite, a lasting reduction in bycatch, has been demonstrated, and can be explained by associative learning: the animal learns to associate the pinger sound with the physical net. Palka et al. (2008) found no increase in mortality of harbour porpoise in 25000 fishing nets with pingers over $7 \mathrm{yr}$ and thus no evidence of 'habituation'. Carretta et al. (2008) reported no increase in mortality over $12 \mathrm{yr}$ of Oregon offshore gillnet fishery. Also, Indo-Pacific bottlenose dolphins did not 'habituate' to $10 \mathrm{kHz}$ Fumunda pingers over 2 separate 1 yr periods in Zanzibar (Amir 2009).

Behavioural studies are extremely difficult to conduct in the wild, partly because of the difficulty in determining and controlling factors that affect behaviour. The reported effectiveness of pingers varies, even when the same species and similar pingers are investigated, although care must be taken to ensure that the scenario is also the same, e.g. bycatch reduction versus depredation mitiga- 
tion. There can be several reasons for this variance, including differences in study paradigms and data analysis, variability in emitted sound characteristics (e.g. as the pinger's age and battery power drops, as emitted SLs decrease), rigging of pingers, context (e.g. water depth, sediment) and simply variability in animal response from population to population-even when belonging to the same species, but living in different geographical and acoustical habitats.

There is a large gap in understanding of the effectiveness of acoustic devices on Australian fauna. QSCP currently deploys 2 types of pingers on shark control nets: Fumunda F3 pingers designed for humpback whales and Fumunda F10 pingers designed for dolphins. The former are deployed seasonally at the time of the humpback migration; the latter are a permanent fixture. This paper assesses the feasibility of bycatch mitigation by pingers on shark control nets, with respect to the following marine mammals along the Queensland coast:

- Humpback whales Megaptera novaeangliae

- Indo-Pacific bottlenose dolphins Tursiops aduncus

- Bottlenose dolphins Tursiops truncatus

- Indo-Pacific humpback dolphins Sousa chinensis

- Common dolphins Delphinus delphis

- Snubfin dolphins Orcaella heinsohni

- Dugongs Dugong dugon

\section{MATERIALS AND METHODS}

\section{Pinger characterisation}

The acoustic characteristics of 3 Fumunda F3 and 3 F10 pingers were measured (www.fumunda.com). Pingers were mounted in a custom-built wooden frame allowing full rotation of the source to measure directivity and ensuring a fixed distance of $2 \mathrm{~m}$ to the recording hydrophone. The entire system was suspended off the side of a boat. Each pinger was measured in horizontal and vertical planes at $30^{\circ}$ increments for $1.5 \mathrm{~min}$ at each angle.

The recording system consisted of a calibrated High Tech HTI96 hydrophone, with built-in preamplifier (sensitivity: $-164 \mathrm{~dB}$ re $1 \mathrm{~V} / \mu \mathrm{Pa}[ \pm 2 \mathrm{~dB}]$; bandwidth: $2 \mathrm{~Hz}$ to $30 \mathrm{kHz}$ ), recording to a Sound Devices SD722 digital audio recorder (sampling frequency: $192 \mathrm{kHz}$; resolution: 24 bits). Custom-written spectral analysis software was used for data analysis. Received levels were back-propagated to calculate SLs using a spherical geometric spreading term: 20 $\log _{10}(2 \mathrm{~m})=6 \mathrm{~dB}$.

\section{Modelling the pinger sound field}

JASCO's Marine Operations Noise Model (MONM) was used to model the 3-dimensional pinger sound field. At low frequencies $(<6 \mathrm{kHz})$, this is achieved via a wide parabolic equation (PE) solution to the acoustic wave equation (Collins 1993). At mid-tohigh frequencies $(>6 \mathrm{kHz})$, a Gaussian-beam ray trace approach is used instead (Porter \& Liu 1995). MONM takes into account the water and seabed properties of the area and can handle variations in the propagation environment with direction, depth and distance from the source.

In shallow-water environments, such as the Gold Coast, eastern Australia, underwater sound propagation is strongly influenced by the geo-acoustic parameters of the seabed, which were taken from the literature (Hamilton 1980, Buckingham 2005, Erbe 2009) (Table 1). We modelled a $30 \mathrm{~m}$ layer of fine sand over sandstone bedrock based on measurements in Moreton Bay and along the Gold Coast (Jones \& Davies 1979, Marshall 1980, Erbe 2009).

Conductivity-temperature-depth (CTD) casts were done on site at the Gold Coast down to $10 \mathrm{~m}$ depth and showed well-mixed water with a mean sound speed of $1523 \mathrm{~m} \mathrm{~s}^{-1}$, slightly increasing by $0.2 \mathrm{~m} \mathrm{~s}^{-1}$ with depth.

Pingers are normally deployed at the bottom of the floating nets, at a constant depth of $6 \mathrm{~m}$ below the sea surface independent of tide, and this source depth was therefore used in the modelling. Low, mean and high tides were modelled with 7,10 and $13 \mathrm{~m}$ water depth, respectively.

Table 1. Geo-acoustic profile parameters used for modelling the seabed at the Gold Coast, Australia. The model can only handle shear (S-wave) properties at the water-sediment interface; therefore no S-parameters are given below $0 \mathrm{~m} . \mathrm{z}$ : depth; $c_{\mathrm{p}}$ and $c_{\mathrm{S}}$ : seismic P-wave and S-wave speeds, respectively; $\rho$ : density; $\alpha_{\mathrm{p}}$ and $\alpha_{\mathrm{s}}$ : seismic P-wave and S-wave attenuations, respectively

\begin{tabular}{|ccccccc|}
\hline Material & $\begin{array}{c}z \\
(\mathrm{~m})\end{array}$ & $\begin{array}{c}C_{\mathrm{p}} \\
\left(\mathrm{m} \mathrm{s}^{-1}\right)\end{array}$ & $\begin{array}{c}\rho \\
\left(\mathrm{g} \mathrm{cm}^{-3}\right)\end{array}$ & $\begin{array}{c}\alpha_{\mathrm{p}} \\
\left(\mathrm{dB} \lambda^{-1}\right)\end{array}$ & $\begin{array}{c}C_{\mathrm{s}} \\
\left(\mathrm{m} \mathrm{s}^{-1}\right)\end{array}$ & $\begin{array}{c}\alpha_{\mathrm{s}} \\
\left(\mathrm{dB} \lambda^{-1}\right)\end{array}$ \\
\hline Fine sand & 0 & 1650 & 1.8 & 0.165 & 418 & 5.5 \\
& 10 & 1700 & 1.6 & 0.17 & & \\
& 20 & 1750 & 1.62 & 0.175 & & \\
& 30 & 1800 & 1.65 & 0.18 & & \\
Sandstone & 35 & 2900 & 2.4 & 0.348 & & \\
bedrock & 40 & 3000 & 2.4 & 0.36 & \\
& 50 & 3500 & 2.5 & 0.42 & \\
& 200 & 3800 & 2.58 & 0.456 & & \\
& 2000 & 4000 & 2.6 & 10 & & \\
\hline
\end{tabular}




\section{Ambient noise measurement}

JASCO's Autonomous Multi-Channel Acoustic Recorder (AMAR) measured underwater sound (sampling frequency: $32 \mathrm{kHz}$; resolution: 24 bits), with a Geospectrum M8 hydrophone (bandwidth: $200 \mathrm{kHz}$ ). The AMAR has a constant noise floor at $-131 \mathrm{~dB}$ re full scale $/ \sqrt{ } \mathrm{Hz}$, which equates to $42 \mathrm{~dB}$ re $1 \mu \mathrm{Pa} / \sqrt{\mathrm{Hz}}$ for an M8 hydrophone.

Table 2. Deployment dates and coordinates of the acoustic recorder

\begin{tabular}{|lcc|}
\hline Deployment & Date & Coordinates \\
\hline 1 & $9 \mathrm{Sep} \mathrm{2010}$ & $27.95971^{\circ} \mathrm{S}, 153.43552^{\circ} \mathrm{E}$ \\
2 & 4 Jan 2011 & $28.03542^{\circ} \mathrm{S}, 153.44434^{\circ} \mathrm{E}$ \\
3 & $11 \mathrm{Mar} 2011$ & $28.03452^{\circ} \mathrm{S}, 153.44404^{\circ} \mathrm{E}$ \\
4 & 14 May 2011 & $28.03452^{\circ} \mathrm{S}, 153.44404^{\circ} \mathrm{E}$ \\
\hline
\end{tabular}

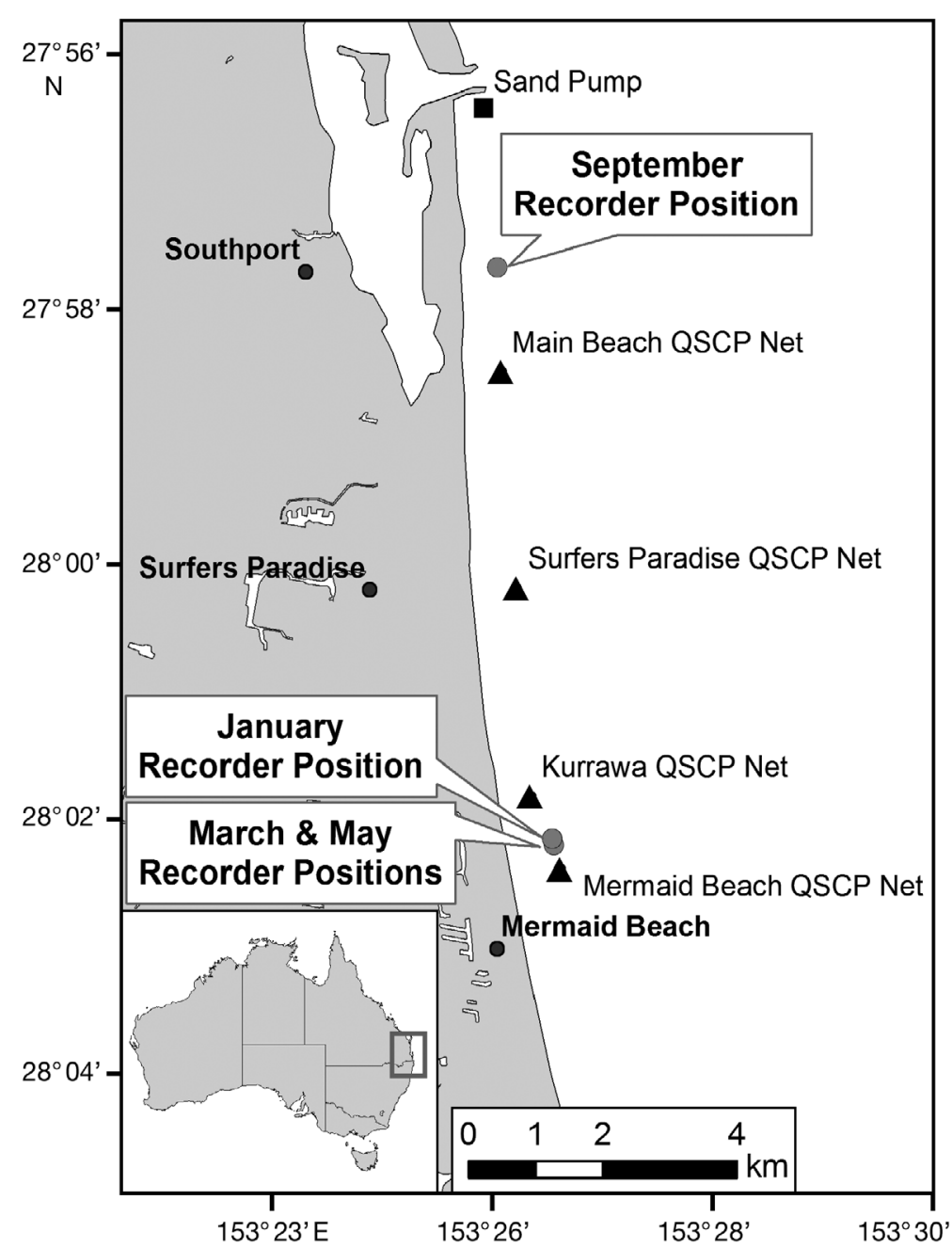

Fig. 1. Gold Coast of Queensland, Australia, showing Queensland Shark Control Program (QSCP) nets and underwater recorder positions
The recorder was deployed for a period of $3 \mathrm{wk} 4$ times during the year at 2 different sites (Table 2). A map of the area is shown in Fig. 1. CTD casts were done using an Instrumentation Northwest AquiStar CT2X.

All recordings were analysed with JASCO's SpectroPlotter software, which displays waveforms and spectrograms and lets the user simultaneously view and listen to sound. Automatic detections were confirmed manually. Spectrogram captions (see Figs. 4 to 6) list the number of Fourier components (NFFT), the window length and the window overlap/advance used for each plot.

The statistical distribution of ambient noise over time was computed by applying a Fast Fourier Transform (FFT) to the recorded time series over $1 \mathrm{~s}$ long windows with $50 \%$ overlap and Hamming windowed, thus calculating power density spectra in $1 \mathrm{~Hz}$ bands. The statistical distribution of levels (percentiles) within each $1 \mathrm{~Hz}$ band was computed. The nth percentile gives the level that was exceeded $\mathrm{n} \%$ of the time; the 50th percentile is equal to the median.

\section{Modelling pinger detectability}

To estimate ranges and regions over which pinger sound is detectable by marine mammals, information on audiograms and critical ratios was gathered. An audiogram is a graphic display of hearing sensitivity (detection levels) at different frequencies. A critical ratio $(C R)$ is the difference in decibels between the sound pressure level of a pure tone just audible in the presence of a continuous noise of constant spectral density and the sound pressure spectrum level for that noise. Numerically, if $I_{\mathrm{t}}$ denotes the intensity of the tone and $\mathrm{PSD}_{\mathrm{n}}$ the power spectral density (intensity per Hertz) of wideband noise at the levels where the tone is just audible through the noise, then the $\mathrm{CR}$ becomes (Erbe 2008):

$$
\mathrm{CR}=10 \log _{10} \frac{I_{\mathrm{t}}}{\mathrm{PSD}_{\mathrm{n}}}
$$

CRs indicate how much higher the intensity of the pinger tone has to be than the intensity of the ambient noise for the pinger tone to be audible. Information on audiograms and CRs is only available for some species that occur in captivity, and is com- 
pletely unknown for baleen whales. In the absence of direct data on hearing sensitivity, we searched for indirect information stemming from observed behavioural responses to sound and from vocalisations emitted by the species in question.

In order to estimate detection ranges of pingers, the modelled transmission loss (see 'Modelling the pinger sound field') was applied to the measured SLs (see 'Pinger characterisation') yielding received levels. These were compared to recorded ambient noise levels (see 'Ambient noise measurement') and to hearing thresholds estimated for the marine mammals above. Given that the pingers operate at one frequency (plus harmonic overtones), the pure-tone detection threshold needs to be subtracted from the received level to determine audibility. This detection threshold is the higher of 2 levels: (1) the audiogram level measured in the absence of noise and (2) the ambient noise power spectrum density level plus the CR (Erbe \& Farmer 2000).

\section{RESULTS}

\section{Pinger characterisation}

Table 3 summarises the measurements of the 6 pingers. The fundamental frequencies of the 3 F3 pingers were a few $100 \mathrm{~Hz}$ below $3 \mathrm{kHz}$, with a $3 \mathrm{~dB}$ bandwidth of 1 to $2 \mathrm{~Hz}$ for all tones. Multiple harmonic overtones existed for each pinger. There was a ping-to-ping variation in the fundamental frequency of 10 to $20 \mathrm{~Hz}$. The ping-toping variation in sound level at a fixed angle was $5 \pm 2 \mathrm{~dB}$ for all F3s. The broadband $(>2 \mathrm{kHz})$ root-mean-squared sound pressure level (SPL $\left.\mathrm{Sms}_{\mathrm{rms}}\right)$ was computed over 5 pings in each direction. At the fundamental frequency, the pingers were mostly omni-directional (variability $<10 \mathrm{~dB}$ ). Shapiro et al. (2009) found levels changed with angle by up to 5 and $26 \mathrm{~dB}$ for a $10 \mathrm{kHz}$ Airmar and a broadband (20 to $160 \mathrm{kHz}$ ) Aquamark pinger, respectively.

For the F10 pingers, the fundamental frequencies were a few $100 \mathrm{~Hz}$ below $10 \mathrm{kHz}$ with a $2 \mathrm{~Hz}$ bandwidth. Multiple harmonic overtones existed. The ping-to-ping variation in sound level at a fixed angle was $5 \pm 2 \mathrm{~dB}$. Output level varied by $<10 \mathrm{~dB}$ as a function of angle. The broadband (>2 kHz) $\mathrm{SPL}_{\mathrm{rms}}$ was computed over 5 pings in each direction. This analysis focussed on energy at the tones of the pingers. Both types of pingers emitted low-frequency noise $(<2 \mathrm{kHz})$, which added up to $12 \mathrm{~dB}$ to broadband levels.

\section{Modelling the pinger sound field}

Pingers are deployed within a few hundred metres from the Gold Coast, which runs roughly north to south. Migrating animals are expected to travel on the east side (deep-water side) of the nets. Acoustic propagation (transmission loss) was modelled in a due-east direction for 4 frequencies: the fundamental $(2.7 \mathrm{kHz})$ and the first 2 harmonic overtones of the F3 pingers (5.4 and $8.1 \mathrm{kHz}$ ), and the nominal fundamental of the F10 pinger $(10 \mathrm{kHz})$. Sound propagation was modelled in 3 dimensions, but, to plot the results, the maximum transmission loss over all depths and angles at each frequency is shown in Fig. 2. Transmission loss varied little with tide $(<10 \%)$.

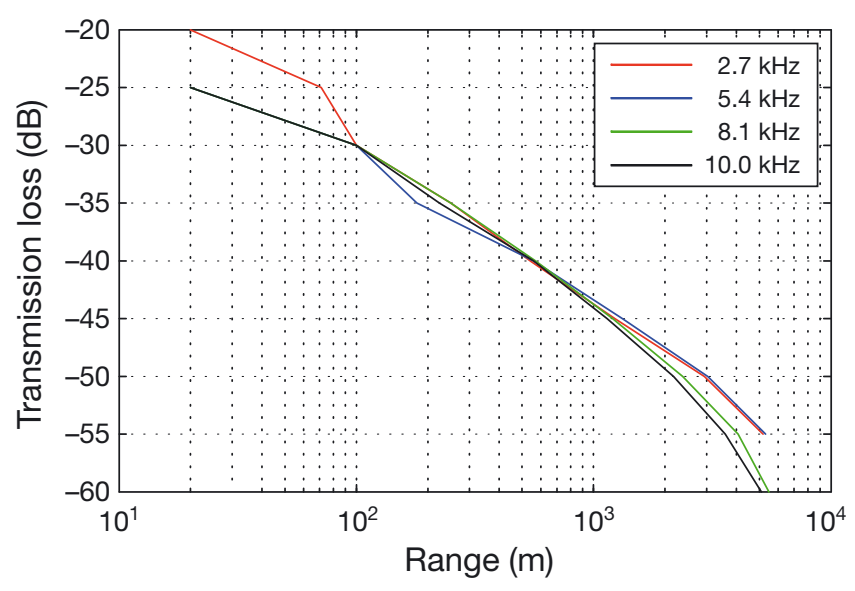

Fig. 2. Transmission loss versus range for 4 pinger frequencies at mean tide level 


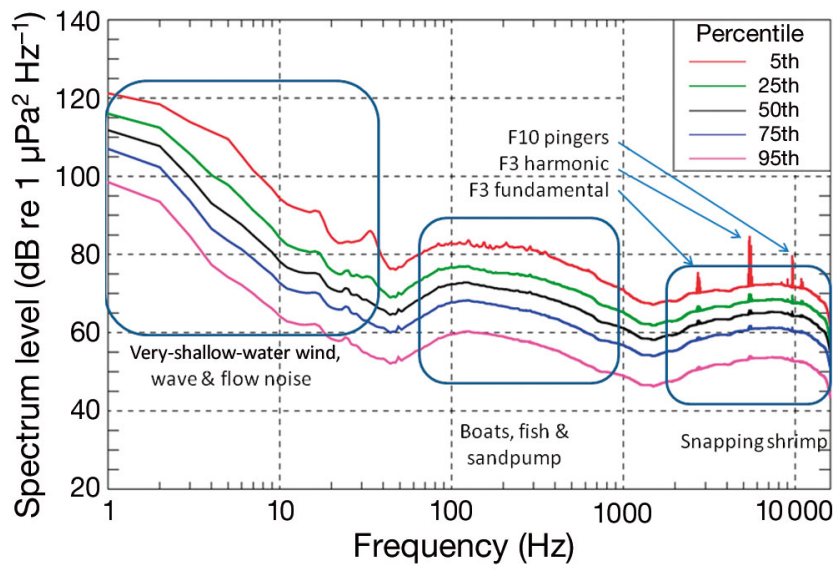

Fig. 3. Ambient noise percentiles for May 2011 off the Gold Coast, $500 \mathrm{~m}$ from the nearest shark net. The nth percentile gives the level that was exceeded $n \%$ of the time. Frames indicate: low frequencies primarily due to wind, wave and flow noise in very shallow water; mid-frequencies, due to boats, fish and a sandpump; high frequencies, due to snapping shrimp received level of the first harmonic overtone of the F3 was higher than its fundamental.

An example of recorded F3 tones is given in Fig. 6. The fundamental was not detectable, but the first overtone (at about $5.4 \mathrm{kHz}$ ) was. Multiple tones were detected simultaneously (close to each other in time) from multiple pingers on the net.

A common concern about pingers is their added contribution to the man-made noise budget. Budgets are often presented as pie charts (Fig. 7), which depend on the quantity plotted. Based on the May 2011 recording and a range of $500 \mathrm{~m}$ from the nearest shark net, pingers contributed similar sound exposure levels (Fig. 7a), yet minimal energy in linear units (Fig. 7b). Shrimp snapping around the clock dominated the energy chart, but boats (of which there were few, yet loud, passes) dominated in terms of power (Fig. 7c). Noise budgets are often computed in terms of one-third-octave-band $\mathrm{SPL}_{\mathrm{rms}}$, but the

\section{Ambient noise levels}

The noise level percentile plot (Fig. 3) shows the typical monthly range of $20 \mathrm{~dB}$ from the 5 th to the 95th percentile. In all of the data, energy at low frequencies $(<30 \mathrm{~Hz})$ was due to wind and wave action over very shallow water, as well as flow noise around the recorder. Levels were $>10 \mathrm{~dB}$ higher in January 2011, compared to the other 3 deployments, due to the strong storms that southeast Queensland experienced at that time. At mid-frequencies (80 to $1000 \mathrm{~Hz}$ ), noise was due to a sandpump operating nightly (20:00 to $24: 00 \mathrm{~h}$ ) at $10 \mathrm{~km}$ range, boats, humpback whales on their southern migration in September (Fig. 4) and on their northern migration in May, and fish (evening chorus). Snapping shrimp typically dominate the ambient spectrum between 2 and $20 \mathrm{~Hz}$. Dolphin whistles (4 to $15 \mathrm{kHz}$ ) were heard throughout the deployments, yet never in large numbers (Fig. 5). The nearest shark net (hence the nearest pingers) was about $500 \mathrm{~m}$ from the recorder in May 2011. The F3's fundamental, the F3's first overtone and the F10's fundamental are clearly visible in Fig. 3. Note that the

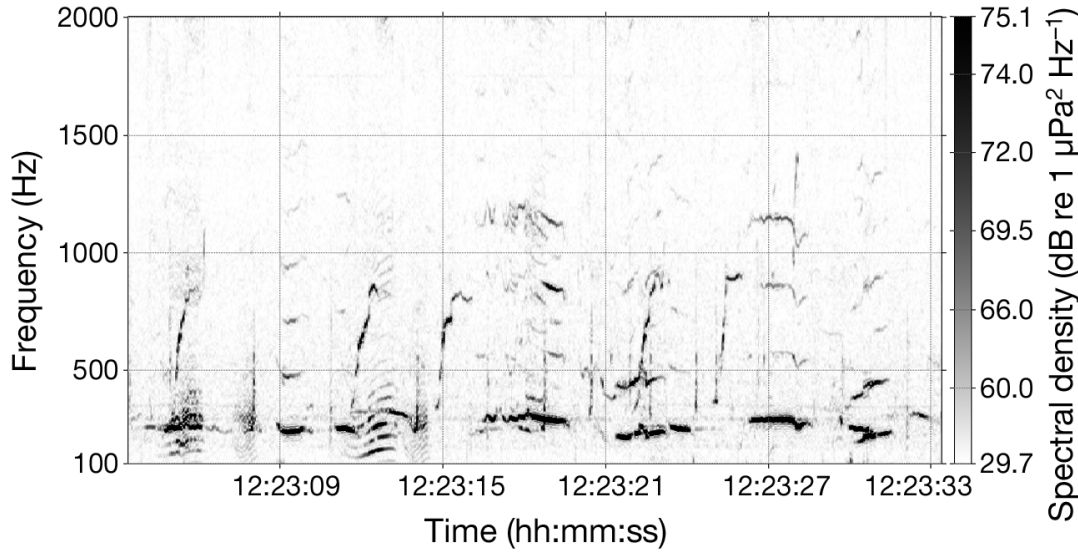

Fig. 4. Megaptera novaeangliae. Humpback calls recorded off the Gold Coast on 15 September 2010 similar to calls reported by Dunlop et al. (2007) (8192 Number of Fast Fourier Transform components [NFFT], $0.1 \mathrm{~s}$ window, $0.05 \mathrm{~s}$ advance)

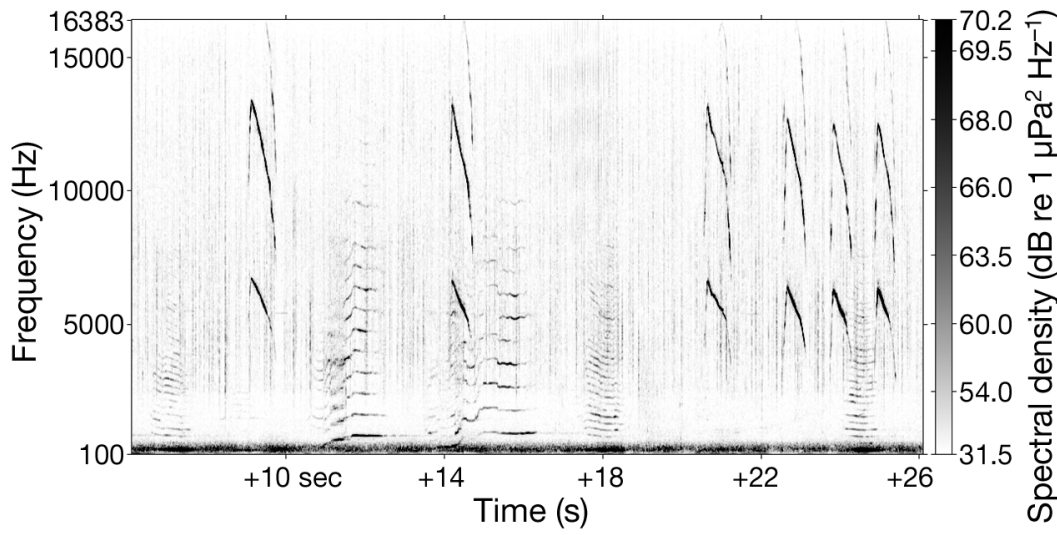

Fig. 5. Dolphin whistles recorded off the Gold Coast, potentially Indo-Pacific bottlenose dolphin Tursiops aduncus, whose whistles have a mean start frequency of around $5 \mathrm{kHz}$ and a mean length of $0.9 \mathrm{~s}$ (Hawkins 2010, Hawkins \& Gartside 2010) (8192 NFFT, $0.1 \mathrm{~s}$ window, $0.05 \mathrm{~s}$ advance) 


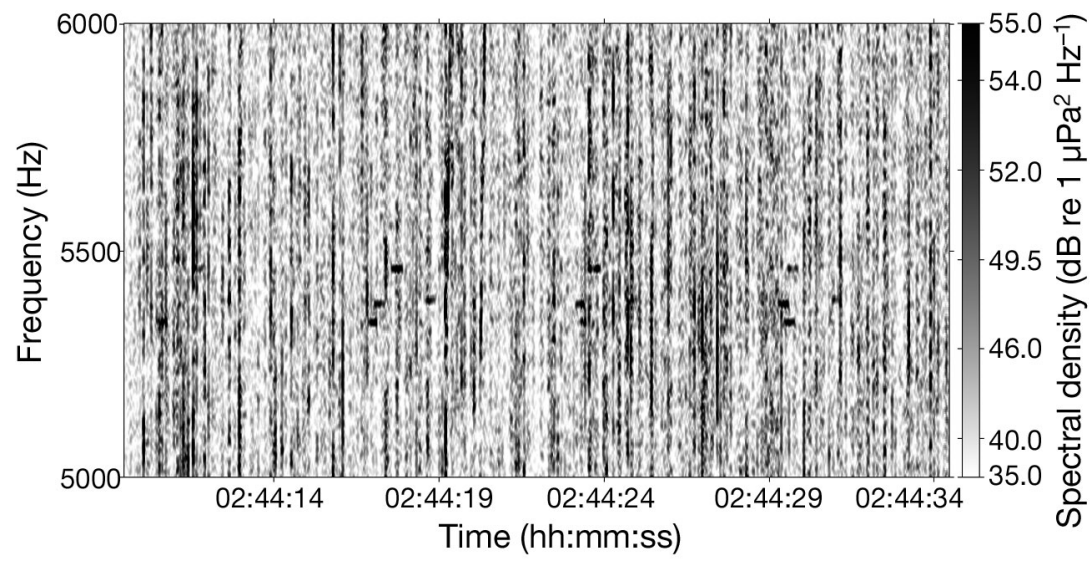

Fig. 6. Spectrogram of F3 pinger overtones (appearing as small black squares) from 4 nearby pingers, on 11 September 2010. Note the variability in frequency $(<150 \mathrm{~Hz})$ and period (changing arrival pattern of the 4 tones). The fundamentals were not visible above ambient levels (16384 NFFT, $0.1 \mathrm{~s}$ window, $0.05 \mathrm{~s}$ advance). Thin vertical lines = snapping shrimp
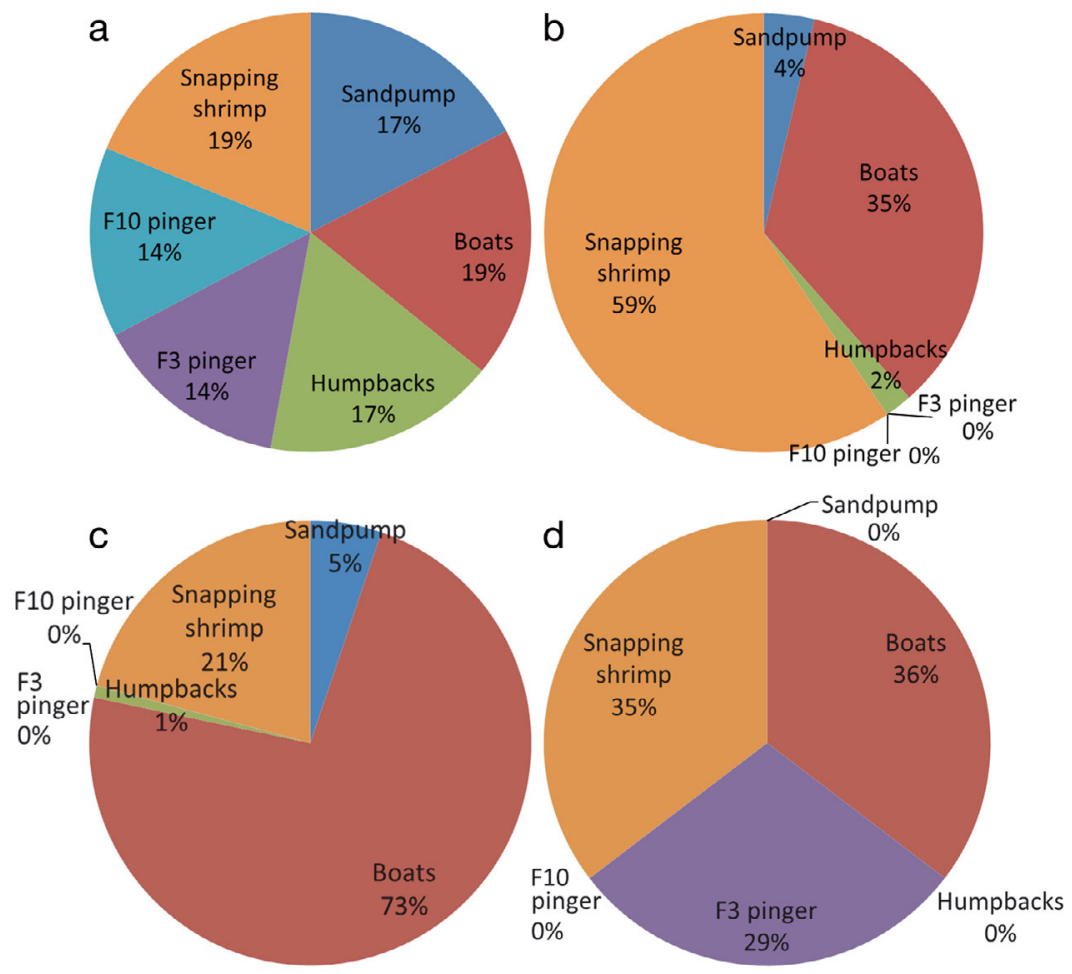

Fig. 7. Pie charts of percentages of sound 'budgets' measured over a $24 \mathrm{~h}$ period at 1 location. (a): sound exposure level in decibel; (b): linear energy; (c):

linear power; $(\mathrm{d})$ : one-third octave sound pressure level centred at $6 \mathrm{kHz}$

outcome will depend on the chosen band. If centred at the F3 fundamental, this pinger obviously contributes significantly (Fig. 7d). A less biased representation of budgets is a percentile plot, which shows energy versus frequency and time (Fig. 3).

\section{Modelling pinger detectability}

Behavioural audiogram measurements that require conditioning or training have not been conducted with baleen whales. (Some were kept at marine parks, but were not trained for hearing.) Several inferences, however, have been made. All animals can hear their own vocalisations, and often the frequency bandwidth of vocalisations overlaps with the frequency range of best hearing sensitivity. Male humpback whales produce song with most of the acoustic energy between $100 \mathrm{~Hz}$ and $4 \mathrm{kHz}$ (Thompson et al. 1979, Payne \& Payne 1985, Cerchio et al. 2001), with components extending to as low as $30 \mathrm{~Hz}$ (Payne \& Payne 1985) and as high as $24 \mathrm{kHz}$ (Au et al. 2006). Both male and female humpback whales further produce social sounds in the same frequency range (Winn et al. 1979, Thompson et al. 1986, Cerchio \& Dahlheim 2001, Dunlop et al. 2007). Anatomical evidence suggests that baleen whales are adapted to low-frequency hearing (Ketten 1991, 1992, 1994, 1997), as their basilar membrane is much broader, thinner and less rigidly supported than that of odontocetes (high-frequency-hearing specialists). Ambient noise in the ocean likely played an evolutionary role in shaping baleen whale audiograms (Clark \& Ellison 2004), such that the dynamic range of the auditory system can be used most efficiently. Following this approach, median ambient noise levels recorded off the Gold Coast were used (Fig. 3), and a CR of $20 \mathrm{~dB}$ was added, based on data measured from other marine mammals (16 to $24 \mathrm{~dB}$ re $1 \mathrm{~Hz}_{\text {; }}$ Richardson et al. 1995) to estimate the humpback audiogram. For example, the median ambient noise level at $3 \mathrm{kHz}$ was $60 \mathrm{~dB}$ re $1 \mu \mathrm{Pa}$. With a CR of $20 \mathrm{~dB}$, this yielded a tone level at the threshold of detectability of $80 \mathrm{~dB}$ re $1 \mu \mathrm{Pa}$. Others have further allowed for a $10 \mathrm{~dB}$ response threshold above detection, yielding a tone level of $90 \mathrm{~dB}$ re $1 \mu \mathrm{Pa}$ at the threshold of response (McPherson et al. 2004). This compares to humpback behavioural 
response thresholds of 80 to $90 \mathrm{~dB}$ re $1 \mu \mathrm{Pa}$ observed in the field in the presence of $4 \mathrm{kHz}$ pingers (Todd et al. 1992).

The bottlenose dolphin Tursiops truncatus is perhaps the most-studied marine mammal in terms of hearing. Johnson (1967) produced the first detailed audiogram showing functional hearing from $100 \mathrm{~Hz}$ to $150 \mathrm{kHz}$ (best sensitivity: 15 to $110 \mathrm{kHz}$ ). Recent behavioural and auditory-evoked-potential measurements show similar results (Brill et al. 2001, Houser \& Finneran 2006, Popov et al. 2007, Houser et al. 2008). CRs of bottlenose dolphins at the Fumunda pinger frequencies were measured by Johnson (1968) and were on average $25 \mathrm{~dB}$ between 5 and $10 \mathrm{kHz}$.

No direct information is available on the hearing capabilities of Indo-Pacific bottlenose dolphins, IndoPacific humpback dolphins or snubfin dolphins. IndoPacific bottlenose dolphins whistle between 5 and $18 \mathrm{kHz}$ (Hawkins \& Gartside 2009b, a, 2010). Characteristics of high-frequency echolocation signals have not been published yet. Indo-Pacific humpback dolphins produce whistles and burst-pulse sounds between $600 \mathrm{~Hz}$ and $>22 \mathrm{kHz}$ (Schultz \& Corkeron 1994, Van Parijs \& Corkeron 2001a,b,c) and echolocation clicks up to $200 \mathrm{kHz}$ (Goold \& Jefferson 2004). Snubfin dolphins produce whistles and burst-pulse sounds between $500 \mathrm{~Hz}$ and $12 \mathrm{kHz}$ (Van Parijs et al. 2000, Kreb 2004) and echolocation clicks up to $130 \mathrm{kHz}$ (Bahl et al. 2007, Inoue et al. 2007). These animals have been shown to respond to man-made noise; however, received levels have not been reported. One auditory brainstem response audiogram has been measured from 1 (sick) common dolphin (Popov \& Klishin 1996, Popov \& Klishin 1998), indicating best sensitivity at $50 \mathrm{kHz}$. Common dolphin whistles are in a range from 3 to $28 \mathrm{kHz}$ (Wakefield
2001, Scullion 2004, Ansmann 2005, Ansmann et al. 2007, Oswald et al. 2007, Gannier et al. 2008, 2010, Griffiths 2009, Petrella et al. 2012). Clicks have a peak energy up to $70 \mathrm{kHz}$ (Evans 1973, Roch et al. 2007). In the absence of direct hearing measures, given the overlap in call frequencies, we used the bottlenose dolphin audiogram and CRs for IndoPacific bottlenose dolphins, humpback dolphins, snubfin dolphins and common dolphins.

A dugong audiogram has never been published. Gerstein et al. (1999) measured underwater behavioural audiograms from 2 manatees Trichechus manatus in captivity, showing peak sensitivity at 10 to $20 \mathrm{kHz}$. Electrophysiological measurements of hearing in manatees indicated peak sensitivity between 2 and $12 \mathrm{kHz}$ (Bullock et al. 1980, Klishin et al. 1990, Popov \& Supin 1990). Dugong vocalisations cover the band from 0.5 to $18 \mathrm{kHz}$ (Anderson \& Barclay 1995, Ichikawa et al. 2006). Peak frequencies of manatee vocalisations range from 3 to $7 \mathrm{kHz}$ (Nowacek et al. 2003). While several studies have documented behavioural responses of dugongs to sound, none determined received levels or behavioural thresholds. In the absence of audiograms for dugongs, we used the behavioural manatee audiogram (Gerstein et al. 1999) for modelling of pinger detectability. In the absence of $\mathrm{CR}$ measurements, we used the mean $20 \mathrm{~dB}$ CR measured from odontocetes at these frequencies (Richardson et al. 1995).

Table 4 lists the frequencies of the measured F3 fundamental $(2.7 \mathrm{kHz})$ and its first 2 harmonic overtones ( 5.4 and $8.1 \mathrm{kHz}$ ) and the approximate F10 fundamental $(10 \mathrm{kHz})$, the measured SLs at these frequencies and the 50th percentile of the ambient noise measured at these frequencies. The hearing threshold for humpback whales was taken as the median ambient noise level plus a $20 \mathrm{~dB}$ CR. The

Table 4. Frequencies of the measured F3 fundamental $(2.7 \mathrm{kHz})$ and its first 2 harmonic overtones $(5.4$ and $8.1 \mathrm{kHz})$ and the approximate F10 fundamental $(10 \mathrm{kHz})$, the measured source levels $(\mathrm{dB}$ re $1 \mu \mathrm{Pa}$ at $1 \mathrm{~m})$ at these frequencies and the 50 th percentile of the ambient noise $(\mathrm{dB}$ re $1 \mu \mathrm{Pa}$ ) measured at these frequencies. The hearing threshold ( $\mathrm{dB}$ re $1 \mu \mathrm{Pa})$ for humpback whales Megaptera novaeangliae was taken as the median ambient noise level plus a $20 \mathrm{~dB}$ critical ratio (CR); the bottlenose dolphin Tursiops truncatus and dugong Dugong dugon hearing thresholds were less than the local ambient noise plus the published CR. Tone detection ranges were computed as the range at which the source level minus the modelled transmission loss equalled the ambient noise plus CR

\begin{tabular}{|c|c|c|c|c|c|c|c|c|c|c|}
\hline \multirow{2}{*}{$\begin{array}{l}\text { Frequency } \\
(\mathrm{kHz})\end{array}$} & \multirow{2}{*}{$\begin{array}{c}\text { Source } \\
\text { level }\end{array}$} & \multirow{2}{*}{$\begin{array}{c}\text { Median } \\
\text { ambient } \\
\text { noise } \\
\text { level }\end{array}$} & \multicolumn{2}{|c|}{ _Humpback whales __ } & \multirow[b]{2}{*}{$\begin{array}{l}\text { Hearing } \\
\text { threshold }\end{array}$} & \multirow{2}{*}{$\begin{array}{c}\text { - Dolphins - } \\
\text { Ambient } \\
\text { noise }+ \\
25 \mathrm{~dB} \mathrm{CR}\end{array}$} & \multirow[b]{2}{*}{$\begin{array}{c}\text { Tone } \\
\text { detection } \\
\text { range }(\mathrm{m})\end{array}$} & \multirow[b]{2}{*}{$\begin{array}{l}\text { Hearing } \\
\text { threshold }\end{array}$} & \multirow{2}{*}{$\begin{array}{c}\text { - Dugong - } \\
\text { Ambient } \\
\text { noise + } \\
20 \mathrm{~dB} \mathrm{CR}\end{array}$} & \multirow[b]{2}{*}{$\begin{array}{c}\text { Tone } \\
\text { detection } \\
\text { range }(\mathrm{m})\end{array}$} \\
\hline & & & $\begin{array}{l}\text { Hearing threshold } \\
\text { (ambient noise } \\
\text { level }+20 \mathrm{~dB} \text { CR) }\end{array}$ & $\begin{array}{c}\text { Tone } \\
\text { detection } \\
\text { range }(\mathrm{m})\end{array}$ & & & & & & \\
\hline 2.7 & 108 & 60 & 80 & 90 & 76 & 85 & 45 & 63 & 80 & 90 \\
\hline 5.4 & 119 & 63 & 83 & 210 & 73 & 88 & 110 & 60 & 83 & 210 \\
\hline 8.1 & 99 & 63 & 83 & 10 & 62 & 88 & 10 & 57 & 83 & 10 \\
\hline 10 & 114 & 62 & 82 & 130 & 58 & 87 & 40 & 55 & 82 & 130 \\
\hline
\end{tabular}


published bottlenose dolphin hearing threshold was used for all 4 dolphin species and compared to ambient levels plus a measured $25 \mathrm{~dB}$ CR. Similarly for dugongs, the published hearing threshold was compared to the ambient level plus a $20 \mathrm{~dB}$ CR. A tone was deemed audible, as long as the received level exceeded both the hearing threshold and the ambient noise plus CR. For dolphins and dugongs, the ambient level plus CR was larger than the hearing threshold; therefore, ambient noise at the Gold Coast determined hearing ranges rather than the audiogram. The tone detection range was computed as the range at which the SL minus the modelled transmission loss equalled the ambient noise plus CR.

There are various ways in which to conceptualise optimal pinger spacing along a shark net. For humans, the primary sense used for navigation is vision; for marine mammals it is audition. An airplane landing in poor light is guided along the runway by a series of lights. Pingers on shark nets are expected to highlight the nets to humpback whales migrating along the Queensland coast. With currently 3 to 4 pingers per net of about $200 \mathrm{~m}$ length, and an F3 detection range of $210 \mathrm{~m}$, all of the F3s would be audible to humpback whales and dugongs anywhere along the net (within a few metres of the net), highlighting the entire net at any 1 location. Only 1 or 2 F10 pingers would be audible to dolphins at any location along the net. Overtones could be audible over longer ranges, given that dolphin hearing sensitivity improves for frequencies $>10 \mathrm{kHz}$, but directionality of the high-frequency signals could counter this advantage.

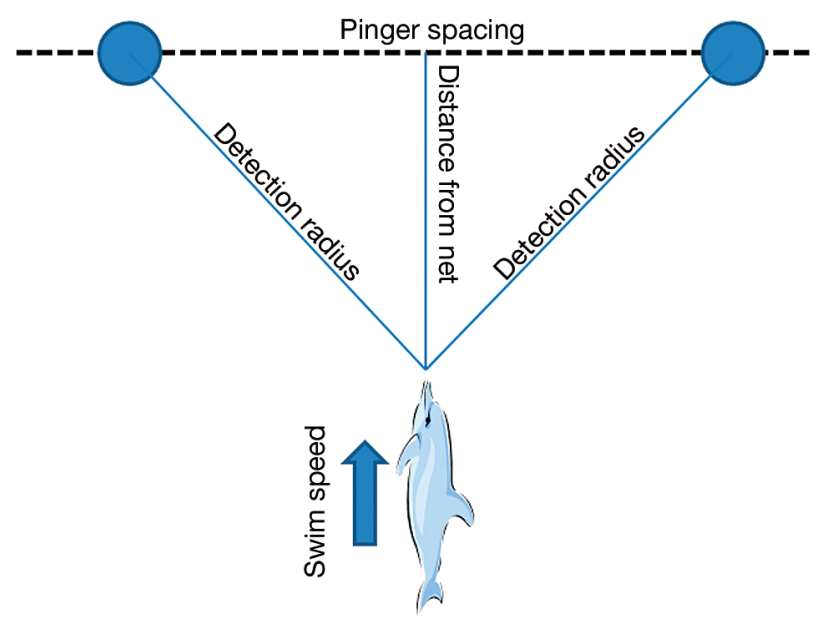

Fig. 8. Sketch of a dolphin swimming towards a net with 2 pingers. The triangle of detection radius and distance from the net determines half of the pinger spacing. The swim speed determines the distance travelled between 2 successive pings
In the case of an animal swimming straight at a net, Fig. 8 shows a worst case, in which the animal is between 2 pingers, hence, it is the farthest distance away from any 1 pinger at which it would be able to detect pings. If the animal swims towards the net at speed $v_{1}$, and if it is just outside the detection radius when the pingers ping, then one would want the next ping to occur before the animal hits the net. This scenario determines a maximum pinger spacing.

Clapham \& Mead (1999) summarised swim speeds published for humpback whales. Relative to other baleen whales of the same family, humpback whales are not fast swimmers. Reported swimming speeds of animals travelling ranged from 1.1 to $4.2 \mathrm{~m} \mathrm{~s}^{-1}$. A maximum burst speed of $7.6 \mathrm{~m} \mathrm{~s}^{-1}$ was measured from a wounded whale being chased by a whaling vessel. Documented swim speeds for bottlenose dolphins are 1.2 to $6.9 \mathrm{~m} \mathrm{~s}^{-1}$ (Fish 1993). The lower speeds are travelling speeds, the higher speeds are non-sustainable burst speeds: 6.0 to $8.3 \mathrm{~m} \mathrm{~s}^{-1}$ (Lang \& Norris 1966, Hui 1987) and $10.2 \mathrm{~m} \mathrm{~s}^{-1}$ (Nursall 1962). Indo-Pacific humpback dolphins are slow swimmers, typically travelling at around $1.3 \mathrm{~m} \mathrm{~s}^{-1}$ (www.arkive. org/indo-pacific-humpback-dolphin/sousa-chinensis/ \#text=Biology). Common dolphins were observed to swim at horizontal speeds of 1.4 tp $1.8 \mathrm{~m} \mathrm{~s}^{-1}$ (Hui 1987), with high speeds of up to $6.7 \mathrm{~m} \mathrm{~s}^{-1}$ (Rohr et al. 2002). Reported dugong speeds range from 2.8 to $6.9 \mathrm{~m} \mathrm{~s}^{-1}$ (www.ioseaturtles.org/Education/dugongbooklet.pdf).

The maximum pinger spacing can be computed via:

$$
d=2 \sqrt{r^{2}-v^{2} T^{2}}
$$

where $d$ is maximum pinger spacing $(\mathrm{m}), r$ is the detection radius (m) (range column in Table 4), $v$ is swim speed $\left(\mathrm{m} \mathrm{s}^{-1}\right)$ and $T$ is quiet time in between 2 pings (s).

With 3 or 4 pingers per $200 \mathrm{~m}$ net, the pinger spacing is about 67 to $100 \mathrm{~m}$. For humpback whales (F3 pingers) and dugong (F3 or F10 pingers), this spacing is more than sufficient. For any of the dolphins (F10 pingers) swimming slower than $6.0 \mathrm{~m} \mathrm{~s}^{-1}$, this spacing is also adequate. If dolphins swim straight at a net at higher speeds, however, the current spacing might not be sufficient to cause timely avoidance.

\section{DISCUSSION}

This study (1) measured the acoustic output of Fumunda F3 and F10 pingers used on shark nets by 
the QSCP, (2) modelled sound propagation, (3) measured ambient noise off the Queensland coast and (4) reviewed the literature to derive the hearing sensitivities of local marine mammals. Combining the results of Points 1 to 4 showed that Fumunda pingers were detectable by all target species (humpback whales, dolphins and dugongs) and were installed at an appropriate depth $(6 \mathrm{~m})$ and spacing (every 67 to $100 \mathrm{~m}$ ) to highlight the net to all animals travelling either parallel or perpendicular to the net.

Several assumptions were made. Pinger output varied with individual pingers and with direction; the mean levels were used in the model of detectability. Sound propagation was modelled based on typical Gold Coast conditions, but will vary with e.g. temperature, time of day, and season. Hearing sensitivity has not been measured for humpback whales, dugongs and some of the local dolphin species, and had to be estimated based on reported behavioural responses, anatomical studies and measurements on related species.

Our study focussed on pinger detectability in the specific ambient noise and sound propagation environment of the Gold Coast. In other environments, and for other target species, the pingers likely require a different arrangement and perhaps different frequencies and SLs.

Pinger detectability was determined by comparing the measured SLs minus the modelled transmission loss to the measured audiograms, as well as measured ambient noise plus CRs. In this sense, our study is a feasibility study, showing that specific pingers in a specific arrangement within a specific environment are audible to specific species. We did not attempt to predict animal behaviour. For a sound to induce a behavioural change, the received level might have to be somewhat larger than the detection level. McPherson et al. (2004) accounted for this by adding a $10 \mathrm{~dB}$ response threshold.

While Fumunda pingers are amongst the quietest pingers commercially available, we showed that they are a feasible choice in this environment and for these specific species. The advantage of using such quiet pingers is their minimal contribution to the overall noise budget. We showed different ways of computing noise budgets and explained why budgets are better represented by power spectrum percentiles than pie charts, as the latter focus on specific frequencies and quantities, ignoring the full spectrum. Ultimately, impact is determined by more than a noise budget and must include an animal's sensitivity to the sound.

\section{Suggestions for future research}

Given the small sample size of pingers measured ( 3 per type), it might be useful to test a larger number of units to achieve a better statistical representation of output levels. It would also be useful to measure at what time into a deployment the battery power becomes inadequate to sustain sufficient output levels, in order to advise on recovery times.

For potential future studies on behavioural responses of marine mammals to pingers, the received sound level should be measured in the field at the time, rather than relying on the manufacturers' specifications in combination with a simple (e.g. geometrical) sound propagation model.

While our acoustic measurements and models indicate that the current pinger design, the sound emission characteristics and the arrangement of pingers on shark nets adequately highlight a net to all target species, the question whether or not this bycatch mitigation solution works is best answered by in situ studies of animal behaviour and simultaneous acoustic monitoring and by long-term monitoring of bycatch rates (in relation to changing population numbers). Barlow \& Cameron (2003) determined reduced bycatch of common dolphins in gillnets when fitted with pingers emitting tones between 10 and $100 \mathrm{kHz}$ at SLs of 120 to $146 \mathrm{~dB}$ re $1 \mu \mathrm{Pa}$ at $1 \mathrm{~m}-$ frequencies and levels similar to the Fumunda pingers studied here.

Acknowledgements. The recorder was deployed with the assistance of Tony Ham and Craig Newton. Andrea McPherson helped with fieldwork and literature reviews. Geoff McPherson, a living encyclopaedia on pingers, provided invaluable advice throughout this study. Caitlin O'Neill performed all sound propagation modelling. This study was supported by a grant from the Australian Marine Mammal Centre, 2010.

\section{LITERATURE CITED}

Amir OA (2009) Biology, ecology and anthropogenic threats of Indo-Pacific bottlenose dolphins in east Africa. PhD dissertation, Stockholm University

Anderson PK, Barclay RMR (1995) Acoustic signals of solitary dugongs: physical characteristics and behavioural correlates. J Mammal 76:1226-1237

Ansmann IC (2005) The whistle repertoire and acoustic behavior or short-beaked common dolphins, Delphinus delphis, around the British Isles, with applications for acoustic surveying. MSc thesis, Bangor University

Ansmann IC, Goold JC, Evans PGH, Simmonds M, Keith SG (2007) Variation in the whistle characteristics of shortbeaked common dolphins, Delphinus delphis, at two locations around the British Isles. J Mar Biol Assoc UK $87: 19-26$ 
$\mathrm{Au}$ WWL, Pack AA, Lammers MO, Herman LM, Deakos $\mathrm{MH}$, Andrews K (2006) Acoustic properties of humpback whale songs. J Acoust Soc Am 120:1103-1110

Bahl R, Ura T, Sugimatsu H, Inoue T and others (2007) Acoustic survey of Irrawaddy dolphin populations in Chilika Lagoon: first test of a compact high-resolution device. In: OCEANS 2006-Asia Pacific Conference, 16-19 May 2006, Singapore. Oceans 2006 Conference Publications, IEEE, Singapore, p 1-6

Barlow J, Cameron GA (2003) Field experiments show that acoustic pingers reduce marine mammal bycatch in the California drift gill net fishery. Mar Mamm Sci 19: 265-283

Berrow S, Cosgrove R, Leeney RH, O'Brien J, McGrath D, Dalgard J, Gall YL (2008) Effect of acoustic deterrents on the behaviour of common dolphins (Delphinus delphis). J Cetacean Res Manag 10:227-233

> Brill RL, Moore PWB, Dankiewicz LA (2001) Assessment of dolphin (Tursiops truncatus) auditory sensitivity and hearing loss using jawphones. J Acoust Soc Am 109: 1717-1722

> Brotons JM, Munilla Z, Grau AM, Rendell L (2008) Do pingers reduce interactions between bottlenose dolphins and nets around the Balearic Islands? Endang Species Res 5:301-308

Buckingham MJ (2005) Compressional and shear wave properties of marine sediments: comparisons between theory and data. J Acoust Soc Am 117:137-152

Bullock TH, Domning DP, Best R (1980) Evoked brain potentials demonstrate hearing in a manatee (Trichechus inunguis). J Mammal 61:130-133

Carretta JV, Barlow J, Enriquez L (2008) Acoustic pingers eliminate beaked whale bycatch in a gillnet fishery. Mar Mamm Sci 24:956-961

Cerchio S, Dahlheim M (2001) Variation in feeding vocalizations of humpback whales (Megaptera novaeangliae) from Southeast Alaska. Bioacoustics 11:277-295

> Cerchio S, Jacobsen JK, Norris TF (2001) Temporal and geographical variation in songs of humpback whales, Megaptera novaeangliae: synchronous change in Hawaiian and Mexican breeding assemblages. Anim Behav 62:313-329

Clapham PJ, Mead JG (1999) Megaptera novaeangliae. Mamm Species 604:1-9

Clark CW, Ellison WT (2004) Potential use of low-frequency sounds by baleen whales for probing the environment: evidence from models and empirical measurements. In: Thomas JA, Moss C, Vater M (eds) Echolocation in bats and dolphins. The University of Chicago Press, Chicago, p 564-582

> Collins MD (1993) A split-step Padé solution for the parabolic equation method. J Acoust Soc Am 93:1736-1742

$>$ Dunlop RA, Noad MJ, Cato DH, Stokes D (2007) The social vocalization repertoire of east Australian migrating humpback whales (Megaptera novaeangliae). J Acoust Soc Am 122:2893-2905

Erbe C (2008) Critical ratios of beluga whales (Delphinapterus leucas) and masked signal duration. J Acoust Soc Am 124:2216-2223

Erbe C (2009) Underwater noise from pile driving in Moreton Bay, Qld. Acoust Aust 37:87-92

Erbe C, Farmer DM (2000) A software model to estimate zones of impact on marine mammals around anthropogenic noise. J Acoust Soc Am 108:1327-1331

Evans WE (1973) Echolocation by marine delphinids and one species of fresh-water dolphin. J Acoust Soc Am 54: 191-199

Fish FE (1993) Power output and propulsive efficiency of swimming bottlenose dolphins (Tursiops truncatus). J Exp Biol 185:179-193

Gannier A, Fuchs S, Oswald J (2008) Pelagic delphinids of the Mediterranean Sea have different whistles. In: New trends for environmental monitoring using passive systems. IEEE, Hyères, p 1-4, doi:10.1109/PASSIVE. 2008.4786982

Gannier A, Fuchs S, Quebre P, Oswald JN (2010) Performance of a contour-based classification method for whistles of Mediterranean delphinids. Appl Acoust 71: 1063-1069

Gerstein ER, Gerstein L, Forsythe SE, Blue JE (1999) The underwater audiogram of the West Indian manatee (Trichechus manatus). J Acoust Soc Am 105:3575-3583

Goold JC, Jefferson TA (2004) A note on clicks recorded from free-ranging Indo-Pacific humpback dolphins, Sousa chinensis. Aquat Mamm 30:175-178

Gotz T, Hastie G (2009) Overview of the impacts of anthropogenic underwater sound in the marine environment. OSPAR Commission, London

Griffiths E (2009) Whistle repertoire analysis of the shortbeaked common dolphin, Delphinus delphis, from the Celtic deep and the eastern tropical Pacific Ocean. MSc thesis, Bangor University

> Hamilton EL (1980) Geoacoustic modeling of the sea floor. J Acoust Soc Am 68:1313-1340

> Hawkins ER (2010) Geographic variations in the whistles of bottlenose dolphins (Tursiops aduncus) along the east and west coasts of Australia. J Acoust Soc Am 128: 924-935

Hawkins ER, Gartside DF (2009a) Interactive behaviours of bottlenose dolphins (Tursiops aduncus) during encounters with vessels. Aquat Mamm 35:259-268

> Hawkins ER, Gartside DF (2009b) Patterns of whistles emitted by wild Indo-Pacific bottlenose dolphins (Tursiops aduncus) during a provisioning program. Aquat Mamm $35: 171-186$

Hawkins ER, Gartside DF (2010) Whistle emissions of IndoPacific bottlenose dolphins (Tursiops aduncus) differ with group composition and surface behaviours. J Acoust Soc Am 127:2652-2663

Hodgson AJ (2004) Dugong behaviour and responses to human influences. PhD disssertation, James Cook University, Townsville

> Hodgson AJ, Marsh H, Delean S, Marcus L (2007) Is attempting to change marine mammal behaviour a generic solution to the bycatch problem? A dugong case study. Anim Conserv 10:263-273

> Houser DS, Finneran JJ (2006) Variation in the hearing sensitivity of a dolphin population determined through the use of evoked potential audiometry. J Acoust Soc Am 120:4090-4099

> Houser DS, Gomez-Rubio A, Finneran JJ (2008) Evoked potential audiometry of 13 bottlenose dolphins (Tursiops truncatus gilli). Mar Mamm Sci 24:28-41

Hui CA (1987) Power and speed of swimming dolphins. J Mammal 68:126-132

> Ichikawa K, Tsutsumi C, Arai N, Akamatsu T, Shinke T, Hara T, Adulyanukosol K (2006) Dugong (Dugong dugon) vocalization patterns recorded by automatic underwater sound monitoring systems. J Acoust Soc Am 119:3726-3733 
Ichikawa K, Akamatsu T, Shinke T, Sasamori K and others (2009) Detection probability of vocalizing dugongs during playback of conspecific calls. J Acoust Soc Am 126: 1954-1959

Inoue T, Ura T, Sugimatsu H Sakamaki T and others (2007) Long duration real-time observation of Irrawaddy dolphins in Chilika lagoon. In: Oceans 2007 Conference 29 Sep-4 Oct 2007, Vancouver. Oceans 2007 Conference Publications, IEEE, Vancouver, p 1-7

Johnson CS (1967) Sound detection thresholds in marine mammals. In: Tavolga W (ed) Marine bioacoustics. Pergamon, New York, NY, p 247-260

- Johnson CS (1968) Masked tonal thresholds in the bottlenosed porpoise. J Acoust Soc Am 44:965-967

> Jones HA, Davies PJ (1979) Preliminary studies of offshore placer deposits, eastern Australia. Mar Geol 30:243-268

Kastelein RA, Jennings N, Verboom WC, de Haan D, Schooneman NM (2006) Differences in the response of a striped dolphin (Stenella coeruleoalba) and a harbour porpoise (Phocoena phocoena) to an acoustic alarm. Mar Environ Res 61:363-378

Kastelein RA, van der Heul S, van der Veen J, Verboom WC, Jennings N, de Haan D, Reijnders PJH (2007) Effects of acoustic alarms, designed to reduce small cetacean bycatch in gillnet fisheries, on the behaviour of North Sea fish species in a large tank. Mar Environ Res 64:160-180

Kastelein RA, Verboom WC, Jennings N, de Haan D, van der Heul S (2008) The influence of 70 and $120 \mathrm{kHz}$ tonal signals on the behavior of harbor porpoises (Phocoena phocoena) in a floating pen. Mar Environ Res 66:319-326

Ketten DR (1991) The marine mammal ear: specializations for aquatic audition and echolocation. In: Webster D, Fay R, Popper AN (eds) The biology of hearing. Springer Verlag, Berlin, p 717-750

Ketten DR (1992) The cetacean ear: form, frequency, and evolution. In: Thomas JA, Kastelein RA, Supin AY (eds) Marine mammal sensory systems. Plenum Press, New York, NY, p 53-75

Ketten DR (1994) Functional analyses of whale ears: adaptations for underwater hearing. IEEE Proc Underwater Acoustics 1:264-270

Ketten DR (1997) Structure and function in whale ears. Bioacoustics 8:103-135

Klishin VO, Diaz RP, Popov VV, Supin AY (1990) Some characteristics of hearing of the Brazilian manatee, Trichechus inunguis. Aquat Mamm 16:139-144

Kreb D (2004) Facultative river dolphins: conservation and social ecology of freshwater and coastal Irrawaddy dolphins in Indonesia. PhD thesis, University of Amsterdam

Lang TG, Norris KS (1966) Swimming speed of a Pacific bottlenose porpoise. Science 151:588-590

Leeney RH, Berrow S, McGrath D, O'Brien J, Cosgrove R, Godley BJ (2007) Effects of pingers on the behaviour of bottlenose dolphins. J Mar Biol Assoc UK 87:129-133

Marshall JF (1980) Continental shelf sediments: southern Queensland and northern New South Wales. Report No. 207, Department of National Development \& Energy, Bureau of Mineral Resources, Geology and Geophysics, Canberra

McPherson GR, Lien J, Gribble NA, Lane B (2001) Review of an acoustic alarm strategy to minimise bycatch of humpback whales in Queensland coastal gill net fisheries. Mem Queensl Mus 47:499-506

McPherson GR, Ballam D, Stapley J, Peverell S and others (2004) Acoustic alarms to reduce marine mammal bycatch from gillnets in Queensland waters: optimising the alarm type and spacing. Annu Conf Australian Acoustical Society, 3-5 November 2004, Gold Coast, Australia. Proc Acoustics 2004, p 363-368

Northridge S, Kingston A (2009) Common dolphin bycatch in UK fisheries. Report No. SC/61, International Whaling Commission, Cambridge

Nowacek DP, Casper BM, Wells RS, Nowacek SM, Mann DA (2003) Intraspecific and geographic variation of West Indian manatee (Trichechus manatus spp.) vocalizations. J Acoust Soc Am 114:66-69

Nursall JR (1962) Swimming and the origin of paired appendages. Am Zool 2:127-141

> Oswald JN, Rankin S, Barlow J, Lammers MO (2007) A tool for real-time acoustic species identification of delphinid whistles. J Acoust Soc Am 122:587-595

Palka DL, Rossman MC, VanAtten AS, Orphanides CD (2008) Effect of pingers on harbour porpoise (Phocoena phocoena) bycatch in the US Northeast gillnet fishery. J Cetacean Res Manag 10:217-226

Payne K, Payne R (1985) Large scale changes over 19 years in songs of humpback whales in Bermuda. Z Tierpsychol 6:89-114

Petrella V, Martinez E, Anderson MG, Stockin KA (2009) Whistle characteristics of common dolphins (Delphinus sp.) in the Hauraki Gulf, New Zealand. Mar Mamm Sci 28:479-496

> Popov VV, Klishin VO (1996) Auditory brain stem responses in characterization of common dolphin (Delphinus delphis) hearing. Dokl Akad Nauk 349:562-564

Popov VV, Klishin VO (1998) EEG study of hearing in the common dolphin, Delphinus delphis. Aquat Mamm 24: 13-20

Popov VV, Supin AY (1990) Electrophysiological studies on hearing in some cetaceans and a manatee. In: Thomas JA, Kastelein RA (eds) Sensory abilities of cetaceans: laboratory and field evidence. Plenum Press, New York, NY, p 405-415

Popov VV, Supin AY, Pletenko MG, Tarakanov MB, Klishin VO, Bulgakova TN, Rosanova EI (2007) Audiogram variability in normal bottlenose dolphins (Tursiops truncatus). Aquat Mamm 33:24-33

Porter M, Liu YC (1995) Finite-element ray tracing. In: Lee $\mathrm{D}$, Schultz $\mathrm{MH}$ (eds) Proceedings of the International Conference on Theoretical and Computational Acoustics, Hawaii. World Scientific, Singapore, p 947-956

Reeves RR, Hofman RJ, Silber GK, Wilkinson D (1996) Acoustic deterrence of harmful marine mammal-fishery interactions. Report No. NMFS-OPR-10 NOAA, Tech Memo, US Department of Commerce, Seattle, WA

Reijnders P (2006) Netherlands progress report on cetacean research, May 2005 to May 2006, with statistical data for the calendar year 2005. Report No. SC/58, International Whaling Commission, Cambridge

Richardson WJ, Greene CR, Malme CI, Thomson DH (1995) Marine mammals and noise. Academic Press, San Diego, CA

Roch MA, Soldevilla MS, Burtenshaw JC, Henderson EE, Hildebrand JA (2007) Gaussian mixture model classification of odontocetes in the Southern California Bight and the Gulf of California. J Acoust Soc Am 121:1737-1748

Rohr JJ, Fish FE, Gilpatrick JWJ (2002) Maximum swim speeds of captive and free-ranging delphinids: critical analysis of extraordinary performance. Mar Mamm Sci 18:1-19 
Schultz KW, Corkeron PJ (1994) Interspecific differences in whistles produced by inshore dolphins in Moreton Bay, Queensland, Australia. Can J Zool 72:1061-1068

Scullion A (2004) Short-beaked common dolphin, Delphinus delphis whistles: whistle density, a reliable form of measuring group size? MSc thesis, Bangor University

Shapiro AD, Tougaard J, Jorgensen PB, Kyhn LA and others (2009) Transmission loss patterns from acoustic harassment and deterrent devices do not always follow geometrical spreading predictions. Mar Mamm Sci 25: 53-67

Stephenson PC, Wells S (2008) Evaluation of the effectiveness of reducing dolphin catches with pingers and exclusion grids in the Pilbara trawl fishery. Fisheries Research Report No. 173, Department of Fisheries, Perth

Thompson TJ, Winn HE, Perkins PJ (1979) Mysticete sounds. In: Winn HE, Olla BL (eds) Behavior of marine animals, Vol 3: Cetaceans. Plenum Press, New York, NY, p 403-431

Thompson PO, Cummings WC, Ha SJ (1986) Sounds, source levels, and associated behavior of humpback whales, southeast Alaska. J Acoust Soc Am 80:735-740

Todd S, Lien J, Verhulst A (1992) Orientation of humpback whales (Megaptera novaeangliae) and minke whales (Balaenoptera acutorostrata) to acoustic alarm devices designed to reduce entrapment in fishing gear. In:

Editorial responsibility: William Perrin,

La Jolla, California, USA
Thomas JA, Kastelein RA, Supin AY (eds) Marine mammal sensory systems. Plenum Press, New York, NY, p 727-739

- Van Parijs SM, Corkeron PJ (2001a) Evidence for signature whistle production by a Pacific humpback dolphin, Sousa chinensis. Mar Mamm Sci 17:944-949

> Van Parijs SM, Corkeron PJ (2001b) Boat traffic affects the acoustic behaviour of Pacific humpback dolphins, Sousa chinensis. J Mar Biol Assoc UK 81:533-538

> Van Parijs SM, Corkeron PJ (2001c) Vocalizations and behaviour of Pacific humpback dolphins Sousa chinensis. Ethology 107:701-716

Van Parijs SM, Parra GJ, Corkeron PJ (2000) Sounds produced by Australian Irrawaddy dolphins, Orcaella brevirostris. J Acoust Soc Am 108:1938-1940

Wakefield ED (2001) The vocal behaviour and distribution of the short-beaked common dolphin Delphinus delphis L. (1785) in the Celtic Sea and adjacent waters, with particular reference to the effects of seismic surveying. Bangor University

Werner T, Kraus S, Read A, Zollett E (2006) Fishing techniques to reduce the bycatch of threatened marine animals. Mar Technol Soc J 40:50-63

Winn HE, Beamish P, Perkins PJ (1979) Sounds of two entrapped humpback whales (Megaptera novaeangliae) in Newfoundland. Mar Biol 55:151-155

Submitted: June 4, 2012; Accepted: September 25, 2012

Proofs received from author(s): December 7, 2012 